\title{
MICROBIOLOGICAL PRODUCTION OF POLYHYDROXBUTYRATES FROM RENEWABLE SOURCES
}

\author{
Rysbek A.B. ${ }^{1,2}$, Kurmanbayev A.A. ${ }^{1}$ \\ ${ }^{1}$ National Center for Biotechnology \\ Korgalzhyn road, 13/5, Nur-Sultan, 010000, Kazakhstan. \\ ${ }^{2}$ L.N. Gumilyov Eurasian National University, \\ 2, Satpayev str., Nur-Sultan, 010000, Kazakhstan. \\ aidana.rysbek9@yandex.ru
}

\begin{abstract}
Plastics play an important role in our daily lives and are used for various purposes. The industry of environmentally friendly products is actively developing in our time, including bioplastics, and much attention of scientists is attracted by biodegradable polymers such as polyhydroxyalacanoates or its subspecies polyhydroxybutyrates, which are synthesized by various microorganisms as a reserve substance, and are also the most acceptable replacement for conventional synthetic plastics. However, the cost of large-scale production of such a biodegradable polymer is not competitive with its wide distribution. Studies of the microbial production of polyhydroxybutyrates should be aimed at identifying cost-effective substrates, as well as determining the appropriate strain of the body for production. These biopolymers have a number of specific properties, such as biodegradability and compatibility with living body tissue, which opens up great opportunities for their use in practice. The final product of polyhydroxybutyrates biodegradation in the environment is water and carbon dioxide, and in a living organism 3-butobutyric acid. The main focus of this review was the production of bioplastics from various economical substrates using various types of bacteria.

Keywords: biopolymer, polyhydroxybutyrate, polyhydroxyalacanoate, renewable source, microbial production, cheap carbon sources; periodic culture.

\section{INTRODUCTION}

Plastic has a special place in the modern world and is used in various fields of activity, such as packaging, construction materials, consumer goods and much more. About 100 million tons of plastics are produced annually in the world [1]. As we know, a synthetic polymer consists of a petrochemical material, which can become a source of environmental pollution for a long time and harm animals. The fight against plastic waste continues, in particular, even in developed countries where there are plastic processing points, not all types of plastic are accepted. And in no other way do plastic polygons accumulate or move, getting blown into the oceans, which exacerbates the situation, posing a threat to wildlife.

The global production of petroleum-based synthetic oils was around 270.0 million tons in 2007. In some developed countries, the process of plastic processing is underway, in this area, countries such as Germany, Japan, South Korea, Slovenia, Austria and others have already achieved some success. About $30 \%$ of plastic is
\end{abstract}


recycled or recycled in EU countries, about $10 \%$ in the USA, while in the vast majority of developing and poor countries this does not happen or is carried out on a very small scale. However, plastic recycling is expensive and not always effective. First of all, garbage collected requires preliminary labor-intensive manual sorting. After this, the plastic has to be cleaned and crushed into small particles. At the same time, current technologies do not allow preserving the properties of plastic: during processing, it turns yellow, loses its presentation and is no longer suitable for the production of food packaging, that is, it cannot be fully used again [2].

And yet, we cannot completely abandon the use of plastic, because it is difficult to imagine a medical institution without disposable syringes or other irreplaceable items of use, but replacing them with biocompatible and also biodegradable plastic is more appropriate and environmentally friendly. The industry of environmentally friendly products today is actively developing, including bioplastics, from starch and glucose syrups. Bioplastics are produced in three directions: by synthesis from monomers, by fermentation by microorganisms, and by polymerization of lactic acid derivatives (polylactides). And now, $80 \%$ of all waste in the world is made up of plastics that are not degradable for a long time of about 100 years.

Polyhydroxyalacanoates (PHA) are the most acceptable replacement for traditional plastics among biodegradable plastics [3], however, the cost of a biological product by $40 \%$ is determined by the price of a carbon source, therefore, the widespread production of PHA is constrained. The most common in a wide range of high molecular weight microbial polyhydroxyalkanoates is poly-3hydroxybutyrate (PHB). Poly (hydroxybutyric acid) (PHB) and other biodegradable polyesters are promising candidates for the development of environment-friendly, totally biodegradable plastics. These polyesters include repeating hydroxyacyl monomers of the general formula: $[-\mathrm{O}-\mathrm{CH}(\mathrm{R})-\mathrm{CH} 2-\mathrm{CO}-] \mathrm{n}$, where $\mathrm{R}=\mathrm{CH} 3$, they are synthesized and stored in the cell cytoplasm as water-insoluble inclusions by various microorganisms and have important commercial value due to their thermoplastic properties and biodegradability. The physical properties of PHB are similar to those of some common plastics. PHB is an intracellular lipid polymer used by bacteria, in the form of energy in conditions of nitrogen deficiency. At present, more than 300 species of PHB synthesizing bacteria are known, in particular, such as Ralstonia eutro PHA, Azotobacter beijerinckia, Bacillus megaterium, Pseudomonas oleovorans, various nitrogen-fixing microorganisms found in the root nodules of the legume family, and many others [4]. However, the global PHA market is still small compared to the production of petroleum-based polymers. According to the latest market data published by European Bioplastics [5], global biopolymer production reached 2.11 million tons in 2018, including 1.4\% PHA.

Although numerous types of bacteria produce PHA and only a few of them are able to accumulate polyesters in large quantities and can be used on a commercial scale fermentation and have advantages that can be divided into 3 aspects: 1) the ability to produce large amounts of intracellular polymer; 2) the ability to grow on a wide range of carbon sources, including found in agricultural waste streams; and 3) penchant for genetic manipulation. for the production of large quantities of polymer [6]. PHA have thermoplasticity, optical activity, antioxidant properties, piezoelectric effect and, most importantly, they are characterized by biodegradability and biocompatibility. The widespread use of PHA makes the product attractive for commerce, PHA have thermoplasticity, optical activity, antioxidant properties, a piezoelectric effect and, most importantly, they are characterized by biodegradability and biocompatibility to produce flexible films, nonwoven materials, medical threads, semi-permeable membranes, various containers, packaging and etc Since PHA is synthesized from various bacteria, this makes it possible to obtain a polymer with 
desired properties with special methods of their cultivation. In the general context of nanomedicines, polymer-based drug delivery systems have generated rapidly growing interest and much effort has been put into combating various diseases, including cancer. Polyester nanoparticle drug delivery systems, including polymerdrug conjugates and amphiphilic block copolymers, are the main class with promising results, especially for those derived from poly (3-hydroxybutyrate) (PHB).

It should be noted that the use of PHA in the manufacture of medical materials requires careful control of the polymer composition, they must be biocompatible, which means they cannot cause serious immune reactions when introduced into the soft tissues or into the blood of the host. PHA materials should also not cause immune reactions during degradation in the body. For suture materials must meet the required strength, toughness and resilience. As a rule, PHA polymers decompose under the influence of nonspecific lipase and esterase in nature.

PHB biosynthesis process. Of considerable interest is the evidence that PHA can consist of various hydroxyalkanoate monomers, and the cloning of genes for its biosynthesis. This led to the production of PHA with various physical properties using genetically engineered microorganisms. The abundant synthesis of PHA requires certain conditions that provide some changes in the synthesis and accumulation of PHA in the metabolism in the cell, the state of the redox process in the cytoplasm and the intracellular ratio of acetyl-CoA / CoA [7].

PHA biosynthesis is divided into three main phases according to [8] (Fig. 1). In phase I, a suitable carbon source enters the cell through simple diffusion or specific transport systems located in the cytoplasmic membrane. In phase II, the compound is intracellularly metabolized to hydroxyacyl-CoA, and it will be a substrate of PHA synthase. In phase III, PHA synthase forms oxo ester bonds, releasing CoA [9].

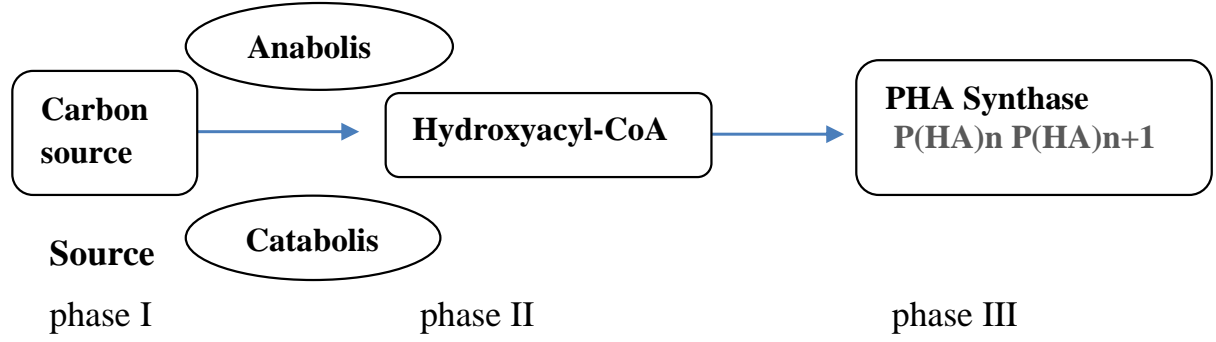

Fig. 1. Phases in the biosynthesis of PHA

Also, environmental conditions for bacterial growth, under unbalanced growth conditions, namely in the absence of one of the macro elements in the medium (nitrogen, phosphorus) or oxygen deficiency, when acetyl-CoA is not included in the tricarboxylic acid (CTK) cycle, and the level of free CoA while low, the activation of enzymes for the synthesis of PHA. The last reaction of the synthesis of PHB is catalyzed by the synthesis of PHB (PHAC), which remains covalently bound to the resulting PHB granule [10]. The unique way in the basis of self-assembly was used by translational fusion of proteins of interest to any end of the PHAC, which ultimately made it possible to obtain PHB granules demonstrating various functions of the protein.

Bacillus megaterium is one of the few bacteria that naturally produces PHB. This was first mentioned by Lemoine in 1926, who described the extracellular substance as polyhydroxybutyrate (PHB) [11]. Other advantages of this organism are its large cell size (up to $1.5 \times 4 \mu \mathrm{m}$ ) and the presence of overexpression systems with strong promoters [12] B. megaterium is a rod-shaped, gram-positive, mainly aerobic, spore-forming bacterium that occurs in various places a habitat. With a cell length of up to $4 \mu \mathrm{m}$ and a diameter of $1.5 \mu \mathrm{m} \mathrm{B}$. Megaterium are one of the most famous 
large bacteria. Cells are often found in pairs and chains [13], where they are connected by polysaccharides on cell walls. To carry out the synthesis of PHB in B. Megaterium cells, various genes of PHB synthase and phasins are involved, which play an important role in the production of $\mathrm{PHB}$ and the formation of granules. Phasin, a protein that separates hydrophobic PHB from the cytoplasm. Thus, phasin can inhibit the fusion of individual granules and contribute to the synthesis of PHB by adjusting the ratio of surface area to volume of PHB granules. PHA may also have a protective function to reduce the passive attachment of cytoplasmic proteins to the surface of PHB. Tian-RenLee scientists and others from Yan-Ming National University reported that the PhaQ gene, which is located before the phasin-encoding PhaP gene, encodes a new class of transcriptional regulator that negatively controls the expression of both PhaQ and PhaP. The PHA binding site was identified using gel mobility shift assays and DNAse I imprint analysis. They also provided evidence that PHA can sense the presence of PHB in vivo and that artificial PHB granules can inhibit the formation of the PHA-DNA complex by invitro by direct binding to PhaQ. This suggests that PHA is a repressor that responds to PHB [14].

PHB is synthesized from the central metabolite of acetyl-CoA, which requires sequential transformations catalyzed by three enzymes. The last reaction of the synthesis of PHB is catalyzed by the synthesis of PHB (PhaC), which remains covalently bound to the emerging PHB granule [15]. The unique main way of selfassembly was progressively harnessed by fusion of proteins of interest to any end of the PhaC, which ultimately allowed the production of PHB granules displaying various protein functions.

PHA metabolism regulation. PHA biosynthesis is regulated by the activity of $\beta$-ketothiolase and acetoacetyl-CoA reductase, while PHA biodegradation depends on the activity of 3-hydroxybutyrate dehydrogenase.

The control of the activation and inhibition of these enzymes is regulated by various compounds that are important factors responsible for their behavior: acetylCoA, free CoA and, to a lesser extent, NADP + or NADPH, ATP, pyruvate and oxacetate. In general, high PHA yields are achieved as a result of an excess of carbon and an energy source, together with a decrease in sulfur, phosphorus, nitrogen, or oxygen [16]. Under conditions of oxygen restriction, the synthesis of PHA allows the cell to regenerate its regenerative power, but if sufficient oxygen is available, CoA increases due to the introduction of acetyl-CoA into the carboxylic acid cycle (TCA also known as citric acid cycle, Krebsaili cycle, less commonly, Saint-GyörgyKrebs). On the other hand, if sulfur is limited, it stops protein synthesis due to the impossibility of producing sulfur-containing amino acids such as methionine or cysteine, and phosphate restriction stops the biosynthesis of nucleic acids. In these two cases, there is an accumulation of NADPH and acetyl-CoA. This increase in energy causes the inhibition of TCA circle enzymes. Consequently, acetyl-CoA accumulates and enters the PHA circle by converting acetyl-CoA to acetoacetyl-CoA via $\beta$-ketothiolase, which can be observed in Figure 2. If the synthesis of cellular components (e.g., proteins) is blocked due to a lack of substrate, PHA synthesis starts. 


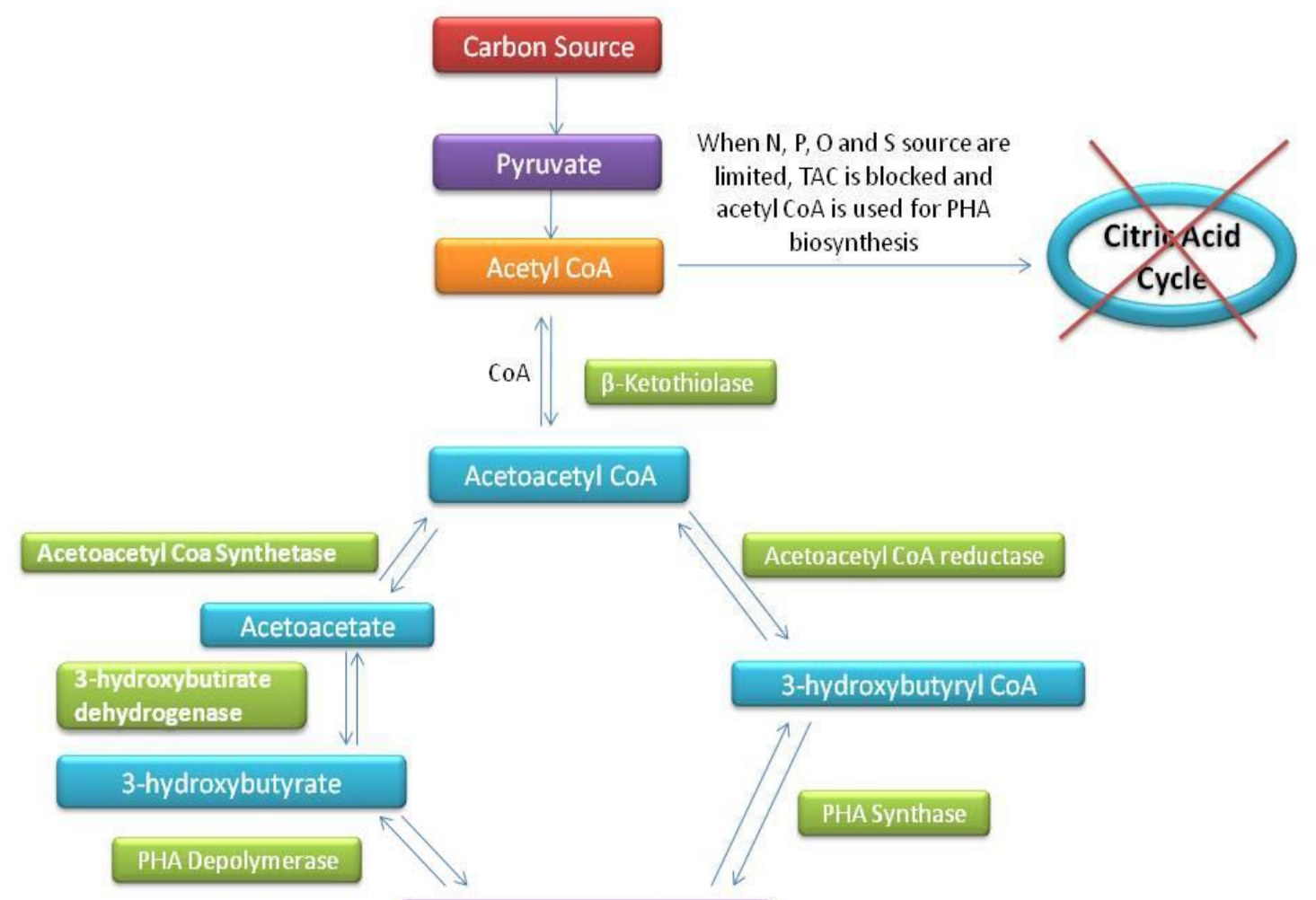

Poly-3-hydroxybutyriate

Fig. 2. Scheme of metabolic pathway I for the biosynthesis of PHB

The common biosynthetic pathway of polyhydroxybutyrate includes three different enzymes that catalyze three different reactions. Three enzymes are encoded by three different genes. In the first reaction, two molecules of acetyl coenzyme A (acetyl-CoA) condense to form acetoacetyl-CoA. This reaction is catalyzed by the enzyme $\beta$-ketothiolase encoded by the PHB gene and catalyzes the formation of a carbon-carbon bond. In the second reaction, acetoacetyl-CoA-A is reduced to $(\mathrm{R})-3$ hydroxybutyryl-CoA using the enzyme acetoacetyl-CoA reductase, which depends on NADPH. Acetoacetyl CoA reductase encoded by the PHBB gene. In the third reaction, PHB synthase encoded by the PHB gene catalyzes the polymerization of R3-hydroxybutyryl-CoA in PHB. Genes encoding the enzymes responsible for the biosynthesis of PHB are located in the PHB CAB operon. The reactions are shown in Fig. 3 and 4. 
Fig. 3 Biosynthetic pathway of PHB

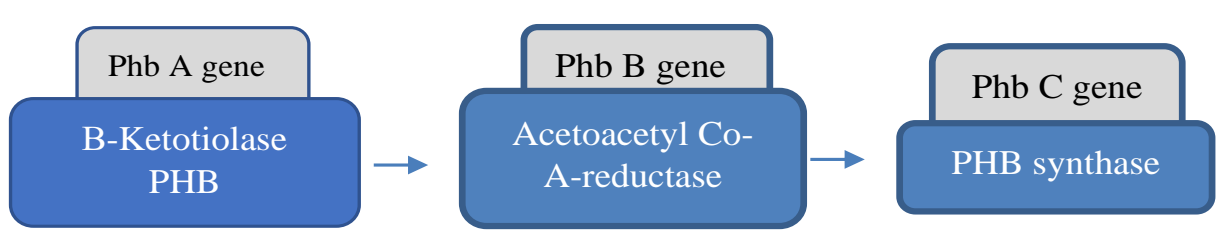

Fig.4 Genes coding enzymes responsible for biosynthesis of PHB [17, 18].

The key molecule that provides the 3-hydroxyalkanoyl-CoA substrate for the synthesis of PHA is acetyl-CoA. The substrate 3-hydroxyalkanoyl-CoA can also be obtained by $\beta$-oxidation of fatty acids. Acyl-CoA, formed on the pathway of $\beta$ oxidation, passes into the process of synthesis of PHA. The precursor for the synthesis of PHA 3-hydroxyacyl-CoA is supplied in the process under the action of various enzymes. Such enzymes are 3-ketoacyl CoA reductase, epimerase, (R) enoyl CoAhydratase / enoyl CoA hydratase 1, acyl CoA oxidase, and enoyl CoA hydratase 1 [18].

Glucose metabolism. PHA is produced from a wide range of substrates, such as renewable resources (sucrose, starch, cellulose, triacylglycerols), fossil resources (methane, mineral oil, lignite, coal), by-products (molasses, whey, glycerin), chemicals (propionic acid, 4-hydroxybutyric acid) and CO2. The bulk of PHA is produced by microorganisms that catabolize glucose along the Enter-Doudoroff (KDPG) pathway, which is found only among prokaryotic organisms [19]. The end product of this pathway is pyruvate, which can be converted by the pyruvate dehydrogenase enzyme system into acetyl-CoA, a key compound in the direction of the TCA circle and PHA biosynthesis, as shown in Figure 5. 


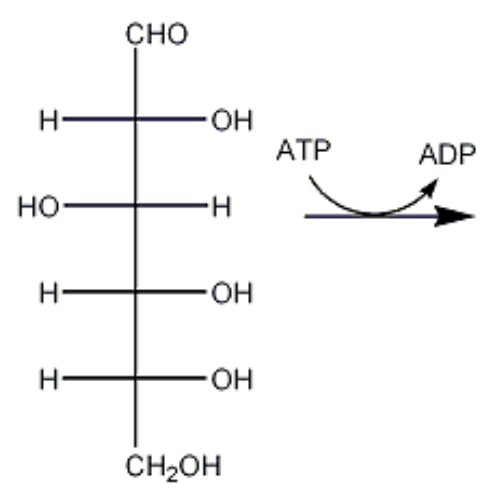

GLUCOSE

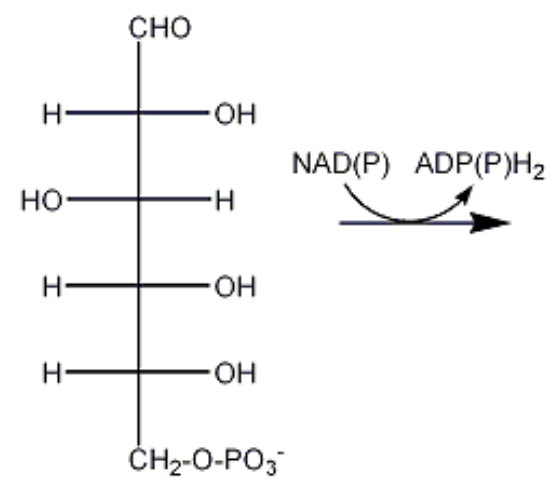

GLUCOSE-6-PHOSPHATE

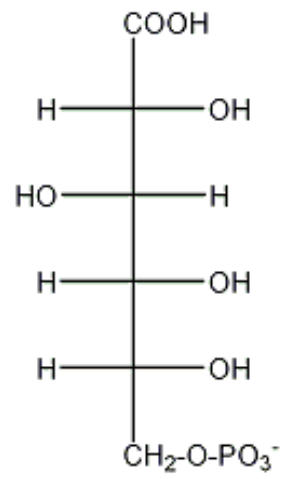

6-PHOSPHOGLUTANATE

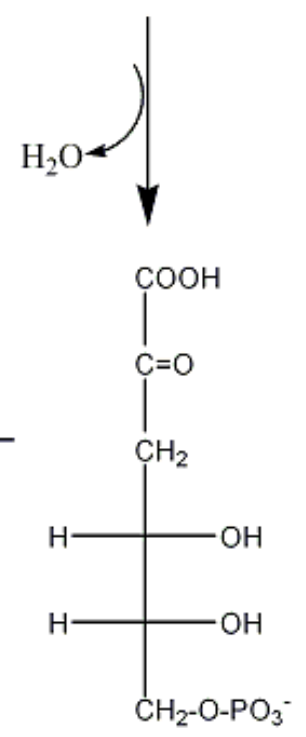

2-KETO-3-DEOXY-6PHOSPHOGLUCONATE

Fig. 5. Glucose metabolism via the Entner-Dudorov path.

Methods for improving the synthesis of PHB. The drawback of the widespread use of PHA is the fact that in most cases their production costs are higher than the costs of conventional petroleum-based plastics. To overcome this problem and be competitive face-to-face with traditional plastics, PGA must have a large production volume at low cost. The high cost of production of PHA is mainly due to the high cost of raw materials, small volumes of production and high costs of processing, especially for the purification and isolation of the polymer.

The cost of the carbon source makes a significant contribution to the total cost of production of PHA, amounting to about $40-50 \%$ of the total cost of production. The trend is to use cheaper feedstock, which does not interfere with the needs of food or feed production, for the production of biopolymers [20-22]. Table 1 summarizes the cost of some types of raw materials already used for the production of PHA [23].

Table 1. The effect of the cost of the substrate on the cost of production of PHBs

\begin{tabular}{|c|l|c|c|}
\hline No. & Substrate & $\begin{array}{l}\text { Estimated price }(€ / \\
\mathrm{kg})\end{array}$ & $\begin{array}{l}\text { The output of PHB } \\
(\mathrm{g} \text { PHB /g substrate })\end{array}$ \\
\hline 1. & Glucose & 0.41 & 0.38 \\
\hline 2. & Sucrose & 0.35 & 0.40 \\
\hline 3. & Ethanol & 0.31 & 0.50 \\
\hline 4. & Methanol & 0.28 & 0.43 \\
\hline 5. & Acetate & 0.59 & 0.38 \\
\hline 6. & Cassava starch & 0.19 & 0.20 \\
\hline 7. & Cheese whey & 0.07 & 0.33
\end{tabular}




\begin{tabular}{|l|l|l|l|}
\hline 8. & Reed treacle & 0.10 & 0.42 \\
\hline 9. & Palm oil & 0.79 & 0.65 \\
\hline 10. & Soybean oil & 0.92 & 0.70 \\
\hline
\end{tabular}

The main goal remains the correlation of the economic effect with the use of cheaper raw materials, with obtaining a producer with high polymer synthesis.

The synthesis of PHA can be carried out by chemical or biological method. High molecular weight PHAs can be obtained when they are synthesized by biological approaches. But the structure of PHAs cannot be predicted when they are biologically obtained [24].

Débora Jung Luvizetto Facci [25] evaluated the effect of oxygen transfer rate on intracellular $\mathrm{P}(3 \mathrm{HB})$ accumulation in order to increase $\mathrm{P}(3 \mathrm{HB})$ synthesized by Bacillus megaterium DSM $32 \mathrm{~T}$ in batch bioreactor cultures. Cultivation on a bioreactor on a laboratory scale was carried out at various volumetric oxygen mass transfer coefficients, $\mathrm{k} \mathrm{L}$ a, when the stirring speed was set to preset values. The results of this work show that oxygen transfer is a key factor in the accumulation of $\mathrm{P}$ (3HB) B. megaterium, increasing the intracellular mass fraction of $\mathrm{P}$ (3HB) from $39 \%$ to $62 \% \mathrm{CDW}$ for $\mathrm{k} \mathrm{L}$ condition $0.006 \mathrm{eva}^{-1}$.

Scientists from the Institute of Biochemistry. A.N. Baha Kosmachevskaya O.V. [26] and others in their study studied the synthesis of poly-3-hydroxybutyric acid (PHB) in the cells of nodule bacteria Rhizobium phaseoli grown in deep culture. We modified the Low method for determining PHB, which allowed us to isolate and determine the amount of polymer directly in biomass. Only S-forms of $R$. Phaseoli cells were capable of synthesizing PHB. On a carbon-rich medium, the accumulation of PHB was stronger (by about 50\%), and the polymer granules were more pronounced. The synthesis of PHB increased with decreasing aeration, and the maximum content was reached by $35-40 \mathrm{~h}$ of growth. The effect of oxidative stress caused by tert-butyl peroxide and benzyl viologen on the growth of bacteria synthesizing PHB was studied. Both substances negatively affected the growth of bacteria, while growth was restored only in the S-form synthesizing PHB. It can be concluded that PHB is a protector for nodule bacteria under oxidative stress. The maximum content of PHB in R. Phaseoli cells reached 54\% of the dry cell mass. This value is close to the values characteristic of bacterial strains - polymer producers used in biotechnology. It can be concluded that nodule bacteria grown in deep culture may be potential producers of PHB and other polyhydroxyalkanoates.

Methods to optimize the composition of the nutrient medium and certain conditions for improving the production of PHB are insufficient, therefore, scientists Grage K. et al. [27] have developed bioengineering to form functional inclusions of PHB in the gram-positive bacterium Bacillus megaterium, which is free of LPS and is well established in industrial production. Since $B$. megaterium is a natural producer of PHB, a PHB-negative strain PHA 05 was used to avoid any background production of PHB. Plasmid-mediated T7 promoter expression of genes encoding $\beta$ ketothiolase (Pha A), acetoacetyl-CoA reductase (Pha B) and PHB synthase (Pha C) allowed the production of PHB in B. megaterium PHA05. To obtain functionalized inclusions of PHB, the N- and C-terminus of PHAC were fused with four and two IgG-binding $\mathrm{Z}$ domains from Staphylococcus aureus, respectively. The PHA ZZ domain fusion protein was strongly produced on the surface of PHB inclusions, and it was found that the corresponding isolated $\mathrm{ZZ}$ domain containing PHB granules purifies IgG with a binding capacity of $40-50 \mathrm{mg} \mathrm{IgG} / \mathrm{g}$ granules. As B. megaterium has the ability to form spores and the corresponding endospores could interact with cellular Purify inclusions, the negative sporulation production strain was generated by disrupting the spo IIE gene in PHA05. This strain did not produce spores when 
tested under conditions causing sporulation, and it was still able to synthesize PHB granules with the $\mathrm{ZZ}$ domain.

Data of scientists Noha S. Elsayed et.al. [28] described in the article on the production of poly (3 - hydroxybutyrate) isolate Azomonasmacro cytogenes KC685000 obtained after 24 hours of incubation of the isolate in a $14 \mathrm{~L}$ fermenter obtained $22 \%$ poly (3-hydroxybutyrate) (PHB) dry biopolymer cell mass (CDW) using aeration of $1 \mu \mathrm{m}, 10 \%$ inoculum size and an initial $\mathrm{pH}$ of 7.2. To control the fermentation process, the Logistic and Leudeking - Piret models were used to describe cell growth and PHB, production, respectively. These two models are in good agreement with experimental data confirming the growth, the associated nature of the production of PHB. The best of method for recovering PHB was chemical digestion using sodium hypochlorite xalone. The obtained polymer was characterized using FT-IR, 1HNMR spectroscopy, gel permeation chromatography, and a transmission electron microscope. Analysis of the nucleotide sequences of the PHA synthase enzyme revealed the tertiary structure of the PHA synthase enzyme, it was analyzed using the modular software approach for predicting structural classes, the Tied Mixture Hidden Markov Model server and the Swiss model software. It was found that the structural class of PHA synthases was a multi-domain protein $(\alpha / \beta)$ containing a conserved cysteine residue and lipase block as characteristic features of the $\alpha$ / $\beta$ hydrolase superfamily. Taken together, all molecular characterization results and images obtained using a transmission electron microscope confirm that the formation of PHB was achieved by improving the model. To our knowledge, this is the first report on the production of growth-related PHB using A. macrocytogenes isolate. KC685000 and its PHA-synth a class III.

A study by Mohamed M. Khattab and Yaser Dahman [29] describes the production and recovery of poly (3 hydroxybutyrate) $\mathrm{P}$ (3HB) from agricultural waste. The production was carried out using the Ralstonia eutropha strain with sugars of hemp biomass hydrolysates Hard as a carbon source and ammonium chloride as a nitrogen source. The results show that a maximum hydrolysis yield of $72.4 \%$ was achieved with a total sugar hydrolysate concentration (i.e. glucose and xylose) of $53.0 \mathrm{~g} / \mathrm{L}$. The sugar metabolism in Ralstonia eutropha has shown preference for glucose metabolism over xylose. Under optimal conditions, cells can accumulate $\mathrm{P}$ (3HB) polymer in an amount of up to $56.3 \mathrm{wt}$. $\%$ dry cells. This corresponds to a total production of $13.4 \mathrm{~g} / 1$ (productivity $0.167 \mathrm{~g} / 1 \mathrm{~h}$ ). The nitrogen source did not show a negative effect on $\mathrm{P}(3 \mathrm{HB})$ biosynthesis, but rather on cell growth. Among several methods investigated, using the ultrasonic assistant sodium dodecyl sulfate (SDS), extracted bioplastics directly from the broth cell concentrate with a $\mathrm{P}(3 \mathrm{HB})$ content of $92 \%$. The number average molecular weights $(\mathrm{Mn})$ of the final reduced bioplastics were in the range of $150-270 \mathrm{kDa}$ with the polydispersity index (Mw / Mn) in the range of 2.1-2.4.

A study by Songsri Kulpreecha et al. [30] Aimed at increasing cell density and producing homopolymer polyhydroxybutyrate (PHB) by Bacillus megaterium BA019, using renewable and inexpensive bioresources as a substrate. A higher cell density and a higher level of PHB production was obtained using sugarcane and urea molasses as sources of carbon and nitrogen, respectively, nitrogen restriction at a molar ratio of C / N 25 led to increased cell growth and PHB production in batch cultures. Fed batch cultivation with a nutrient consisting of MSM with sugarcane molasses, urea and trace elements, and controlled by controlling the $\mathrm{pH}$-stat, leads to a significant increase in cell concentration and PHB production. Optimal for supplying a nutrient medium in this system, a higher total sugar concentration (400 g / 1) and a C / $\mathrm{N}$ molar ratio of $10 \mathrm{~mol} / \mathrm{mol}$ are required. Under these conditions, the highest achieved cell mass (72.6 g / L DW) and the PHB content ( $42 \%$ of the dry cell 
weight) were achieved in a short time, the cultivation time (24 hours), which leads to an increase in the productivity of PHB (1.27 g/1/ hour). However, dissolved oxygen was limiting and, therefore, the system is likely to be suboptimal and capable of even further improving the rate of PHB production.

To add value to biomass, waste from agriculture, food processing plants and municipal organic waste can be used to produce biopolymers such as biohydrogen and biogas through various microbial processes. In fact, various bacterial strains can synthesize biopolymers to convert waste into valuable intracellular (e.g. polyhydroxyalkanoates) and extracellular (e.g. exo polysaccharides) bio products that are useful for biochemical production. In particular, a large number of bacteria, including Alcaligenes eutrophus, Alcaligenes latus, Azotobacter vinelandii, Azotobacter chroococcum, Azotobacter beijerincki, methylotrophs, Pseudomonas spp., Bacillus spp., Rhizobium spp., Escherichia., used for the production of polyhydroxyalkanoates on an industrial scale from various types of organic byproducts. Thus, the development of highly effective microbial strains and the use of by-products and waste as substrates can reasonably make the costs of producing biodegradable polymers comparable to those needed for plastics derived from petrochemicals and stimulate their use. Many studies report the use of the same organic substrates as alternative energy sources for the production of biogas and biohydrogen by anaerobic digestion, as well as the processes of darkness and photo fermentation under anaerobic conditions. Therefore, the simultaneous production of bioenergy and biopolymers at a reasonable price through an integrated system becomes possible using by-products and waste as sources of organic carbon. Overview of suitable substrates and microbial strains used in inexpensive polyhydroxyalkanoates for the production of biohydrogen and biogas. The possibility of creating a unique integrated system is being discussed, as it represents a new approach for the simultaneous production of energy and biopolymers for the plastic industry using by-products and waste as sources of organic carbon [31].

Azotobacter vinelandii $O P$ is a bacterium that produces poly (3hydroxybutyrate) (PHB). Díaz-Barrera et al. [32] evaluated the production of PHB in a stirred bioreactor using various oxygen transfer strategies. Using different oxygen content in the inlet gas, the oxygen transfer rate (OTR) was changed at a constant mixing speed. Periodic cultures were carried out without monitoring the dissolved oxygen tension (DOT) (using 9\% and $21 \%$ oxygen in the inlet gas) and under the control of DOT (4\%) using gas mixing, the culture was grown on a medium with sucrose. Cultures that developed without DOT control were limited to oxygen. As a result of changes in the oxygen content in the inlet gas, OTR decreases $(4.6 \mathrm{mmol} 1$ $1 \mathrm{~h}-1)$ and the specific oxygen absorption rate (11.6 mmol $\mathrm{g}-1 \mathrm{~h} \mathrm{-1)}$ was obtained using $9 \%$ oxygen in the inlet gas. The use of $9 \%$ oxygen in the inlet gas was most suitable for improving the content of intracellular PHB (56 \pm 6 wt. -1$)$. For the first time, PHB accumulation in A. vinelandii OP culture developed with different OTRs was compared under conditions of homogeneous mixing, demonstrating that bacterial respiration affects the synthesis of PHB. These results can be used to develop new oxygen transfer strategies for the production of PHB under production conditions.

Kulpreecha et al. [33] tested B. megaterium BA-019 on sugarcane molasses (20 $\mathrm{g} / \mathrm{l}$ ) as a carbon source and urea or ammonium sulfate at $0.8 \mathrm{~g} / 1$ as the studied nitrogen sources. In these experiments, a cell dry matter concentration of $72.7 \mathrm{~g} / \mathrm{L}$ was achieved in 24 hours with a PHB content of $42 \%$. In conditions of limitation of nitrogen operating in recharge mode. In addition, with sugarcane, $C$. necator showed the best concentration of PHA among bacterial strains (recombinant E. coli, $A$. vinelandii $\mathrm{UWD}$, and $\mathrm{B}$. megaterium) working in the mode of feeding with molasses 
as a carbon source. In fact, $C$. necator is able to accumulate approximately $100 \mathrm{~g} / 1$ of synthesizing glucose (from starch) and sucrose (from sugarcane).

Ramdane Haddouche et al. [34] found the ability to produce polyhydroxyalkanoates (PHA) by recombinant strains of oil-containing yeast Yarrowia lipolytica expressing the PHA synthase gene (PHAC) from Pseudomonas aeruginosa in peroxisome.The yield of PHA, but not the composition of the monomer, depended on the POX genotype (coding for POX acyl CoA oxidase genes). In this study of variants of $Y$. lipolytica $\beta$-oxidation is a multifunctional enzyme, with deletions or inactivation of the R-3-hydroxyacyl-CoA-dehydrogenase domain, we were able to obtain heteropolymers (functional enzyme MFE) or homopolymers (without 3-hydroxyacyl-CoA-dehydrogenase activity) PHA consisting mainly of 3-hydroxyacid monomers $(>80 \%)$ of the same length as the external fatty acid, used for growth redirection of the flow of fatty acids towards $\beta$ oxidation deletion of the neutral lipid synthesis pathway (mutant strain Q4 lacks acyl tansferaz encoded by LRO1, genes DGA1, DGA2 and ARE1) combined with one expressing only domain enoyl-CoA hydratase 2 , resulted in a significant increase in the level of PHA, up to $7.3 \%$ of suh. mass cells. Finally, the presence of shorter monomers (up to $20 \%$ of monomers) in the mutant strain lacking the peroxisomal 3hydroxyacyl-CoA dehydrogenase domain provided evidence for partial mitochondrial $\beta$-oxidation in Y. Lipolytica.

In a study by Tripati A.D. et al. [35], Depending on availability and cheaper costs, various carbon sources were tested for the production of PHA (polyhydroxyalkonoates) by the soil bacterium Pseudomonas aeruginosa, and it was found that the waste from the sugar factory (cane molasses) yields a maximum PHA (biodegradable polymer). Urea served as a powerful source of nitrogen compared to other inorganic sources of nitrogen in the synthesis of bioplastics. The influence of various physical parameters, namely; $\mathrm{pH}$, temperature and mixing speed were also studied at the PHA. The kinetics of periodic cultivation under optimized cultural and physical conditions showed a maximum cell mass and PHA concentration of $7.32 \pm$ 0.2 and $5.60 \pm 0.3 \mathrm{~g} / 1$, respectively, after 54 hours of cultivation. Sugar factory waste (total sugar $4 \%$ ) and urea $(0.8 \%)$ improved the efficiency of the process, which showed a yield (Y P / X) of 0.70 at a rate of $0.11 \mathrm{~g} / 1 / \mathrm{h}$. PHA was further characterized as PHB using infrared spectroscopy with Fourier transform (FT-IR).

Scientists Myshkina V.L. from the Institute of Biochemistry. A.N. Bakha [36] RAS the ability of the Azotobacter chroococcum $7 B$ strain, producer of polyhydroxybutyrate (PHB), to synthesize its copolymer poly-3-hydroxybutyrate-3hydroxyvalerate (PHB - GV) was studied. It was shown for the first time that the A.chroococum $7 B$ strain is able to synthesize $\mathrm{PHB}-\mathrm{HB}$ with a different molar percentage of the inclusion of hydroxyvalerate $(\mathrm{HB})$ in the polymer chain when grown on sucrose medium with the addition of carboxylic acids as precursors of the HB units in the PHB chain: valerianic (from 13.1 to $21.6 \mathrm{~mol} \%$ ), propionic (3.1 $\mathrm{mol} \%)$ and hexanoic $(2.1 \mathrm{~mol} \%)$ acids. The qualitative and functional difference between PHB and PHB-HB is shown by the example of the kinetics of the yield of methyl red from films made from synthesized polymers. The maximum inclusion of HS in the polymer chain $(28.8 \mathrm{~mol} \%)$ was noted with the additional introduction of $0.1 \%$ peptone into the nutrient medium against $20 \mathrm{mM}$ valerate. The data obtained allow us to consider the strain as a potential producer of not only PHB, but also PHB-HB.

According to the methods of cultivation of PHB synthesizing bacteria, A. Nemoykina [37] in her work, she estimated the accumulation of alginate and PHB synthesizing Azotobacter vinelandii BIMB216 bacteria when cultured in flasks with different mixing frequencies. At a stirring frequency of $200 \mathrm{rpm}$, a high conversion 
of the carbon source to alginate was observed, while at $100 \mathrm{rpm}$ the carbon source was converted to PHB. The maximum biomass concentration was obtained in cultures grown at $200 \mathrm{rpm} 4.2+-0.1 \mathrm{~g} / 1$.

Analysis of the literature indicates the active development of research aimed at studying the synthesis and structure of polymers based on derivatives of carboxylic acids, table 2 presents a list of PHA-producing bacteria and used renewable sources.

Table 2. List of PHA-producing bacteria and renewable sources used

\begin{tabular}{|c|c|c|c|c|}
\hline Substrate used & Strain & $\begin{array}{l}\text { PHA } \\
(\mathrm{g} / \mathrm{L})\end{array}$ & $\begin{array}{c}\text { PHA } \\
(\%)\end{array}$ & $\begin{array}{l}\text { Referen } \\
\text { ces }\end{array}$ \\
\hline Pea flour & Rhizobium phaseoli & & 54 & {$[27]$} \\
\hline $\mathrm{Lb}$ & $\begin{array}{l}\text { Azomonasmacro cytogenes } \\
\text { KC685000 }\end{array}$ & 0,3 & 22 & [29] \\
\hline Lignocellulosic substrate & Ralstonia eutropha & 1,3 & 56,33 & {$[30]$} \\
\hline $\begin{array}{l}\text { Sugarcane and urea stocks as carbon } \\
\text { sources }\end{array}$ & Bacillus megaterium BA-019 & 1,27 & 42 & [31] \\
\hline Sucrose and Oxygen Medium & Azotobacter vinelandii & $56 \pm 6$ & & [33] \\
\hline Sugarcane & C. necator & 1,2 & 42 & [34] \\
\hline Tridecanoic acid & Yarrowia lipolytica & & 7,3 & [35] \\
\hline Sugar factory waste (cane molasses) & Pseudomonas aeruginosa & $\begin{array}{l}5,60 \pm \\
0,3\end{array}$ & & [36] \\
\hline $\begin{array}{l}\text { Carbohydrate medium with different } \\
\text { mixing frequencies }\end{array}$ & $\begin{array}{l}\text { Azotobacter vinelandii } \\
\text { БИМ В216 }\end{array}$ & 4,2 & & [38] \\
\hline Cashew apple, Jawar stem, Neera & Bacillus subtilis & $\begin{array}{l}0.027 \\
0.034 \\
0.284\end{array}$ & & [39] \\
\hline Cashew Apple, Jawar Stem, Neera & Bacillus cereus & $\begin{array}{l}0.054 \\
0.049 \\
0.152\end{array}$ & & [39] \\
\hline Sugarcane Bagasse, Grapes Pulp, & Bacillus megaterium & $\begin{array}{l}0.198 \\
0.006 \\
0.079\end{array}$ & & [39] \\
\hline Beet molasses & $\begin{array}{l}\text { Bacillus megaterium, } \\
\text { BacillusCereus, } \\
\text { Bacillus subtilis }\end{array}$ & & $\begin{array}{l}41, \\
25, \\
0.5\end{array}$ & [40] \\
\hline Card board industrial effluent & Bacillus sp. NA10 & 3.952 & & {$[41]$} \\
\hline Volatile fatty acids & Ps. putida $\mathrm{CA}-3$ & 1.56 & 39 & [41] \\
\hline Fatty acids & Ps. putida Bet001 & $\begin{array}{l}9.8- \\
15.5\end{array}$ & $\begin{array}{c}49.7- \\
68.9\end{array}$ & [42] \\
\hline
\end{tabular}

Methods for determining PHB. Careful screening of producer bacteria is the basis of the experiment, and today there are two main methods for detecting PHB of synthesizing bacteria from the environment, namely, screening based on the phenotype and based on the genotype. There are many phenotypic discoveries of methods for detecting intracellular granules of PHA that are used to screen manufacturers of PHA, including staining Sudan with black B [43]. Nile blue A staining [44] and Nile red, resulting in dark blue or fluorescent granules. Alternative staining methods have been developed to directly stain colonies or grow bacteria on plates containing Nile Blue A or Nile Red, resulting in fluorescent colonies that can be visualized using UV light. Colonies producing PHA on dishes containing black Sudan B appear black and blue [45]. It was reported that PHA stained with Nile red exhibit similar fluorescence behavior, with a maximum at a radiation wavelength between 540 and $560 \mathrm{~nm}$ and a radiation wavelength between 570 and $605 \mathrm{~nm}$, detected by fluorescence spectroscopy or flow cytometry. This is suitable for 
analyzing the size distribution of granules in biotechnology. Staining of cell suspensions during cultivation experiments showed that Nile red has a high potential for the quantification of hydrophobic bacterial polyhydroxyalkanoic acids. Such optical methods offer the advantages of real-time online monitoring with high specificity.

In the work of O. V. Kosmachevskaya [26], a solution of Nile red in dimethyl sulfoxide, $0.55 \mathrm{mg} / \mathrm{ml}$, was used. Cells selected at a certain stage of growth were destroyed by ultrasound. The destroyed cells were centrifuged and resuspended in water to $\mathrm{A} 600=0.1$. To $3 \mathrm{ml}$ of a suspension of destroyed cells was added $41 \mu \mathrm{l}$ of a solution of Nile red to a final concentration of $7.5 \mu \mathrm{g} / \mathrm{ml}$. The suspension was incubated for $30 \mathrm{~min}$ in the dark at room temperature. Stained samples were centrifuged and resuspended in $3 \mathrm{ml}$ of water. Studies have also been conducted with whole cells. In this case, a Nile red solution was added to $3 \mathrm{ml}$ of a standardized cell suspension. A further procedure was performed as described above. Stained cells were centrifuged and resuspended in $3 \mathrm{ml}$ of water.

The content of PHB in biomass in the work of V. A. Ezhov et al. [46] From methanol Methyloligella halotolerans $C 2$ was determined by reverse phase HPLC on a SIX C18 column $(5 \mu \mathrm{m})$. For this, samples of dry biomass hydrolyzed conc. $\mathrm{H} 2 \mathrm{SO} 4$ at $100{ }^{\circ} \mathrm{C}$ for $1 \mathrm{~h}$, then the hydrolyzate was neutralized with $5 \mathrm{~N} \mathrm{NaOH}$ and centrifuged for $20 \mathrm{~min}$ at $5000 \mathrm{~g}$. The supernatant was applied to the column and eluted with methanol - water (1:1) at a rate of $0.4 \mathrm{ml} / \mathrm{min}$. The PHB content in the eluates was determined spectrophotometrically at $228 \mathrm{~nm}$ using a UVIS $200 \mathrm{UV}$ detector (Linear, United States) using a calibration curve.

Batch fermentation was carried out in $250 \mathrm{ml}$ Erlenmeyer flasks containing 100 $\mathrm{ml}$ of culture medium. The flasks were inoculated and kept at $30^{\circ} \mathrm{C}$ and $130 \mathrm{rpm}$ for the required time. For large-scale production, a 10-liter bioreactor was used that contained $4 \mathrm{~L}$ of culture medium.

Cells were harvested by centrifugation at $10,000 \mathrm{rpm}$. for $10 \mathrm{~min}$ in a centrifuge (Heraeus Sepatech Biofuge 28 Rs, Germany) at $20^{\circ} \mathrm{C}$ and lyophilized in the laboratory.

The polyhydroxybutyrate polymer obtained by the selected PHB-positive isolates is isolated and quantified numb using the sodium hypochlorite method given by Lawand Slepecky with slight modifications [47-48]. The amount of PHB produced is calculated with reference to a standard curve prepared using pure PHB (Sigma-Aldrich) [49].

\section{DISCUSSION and CONCLUSIONS}

The development of PHA in the mass chemical industry will solve at least three problems: the use of petroleum for plastic materials, the reduction of $\mathrm{CO}_{2}$ emissions and environmental protection. This is due to the sustainable development of the chemical industry. To reduce the cost of producing PHA, much more work needs to be done so that PHA-based biofuels can be added to existing bio-based fuels, including ethanol, propanol, butanol, biodiesel, hydrogen and methane gas.

Based on a literature review, physical parameters are established that are a key factor for the accumulation of PHB, namely: $\mathrm{pH}$, temperature, mixing speed and oxygen transfer. The kinetics of batch cultivation under optimized cultural and physical conditions showed maximum cell mass and PHA concentration. The synthesis of PHB increased with decreasing aeration, and the maximum content was reached up to $66 \%$.

The protective function of PHB for bacteria is to mobilize energy reserves in case of stressful situations, including a lack of carbohydrates. It is known that PHB 
can protect the cell from other stressful effects: heat and osmotic shock, UV radiation, the effects of oxidizing agents. PHB accumulates in prokaryotic cells under conditions of unbalanced growth and acts as a reserve substance for storing carbon and energy, like fat, glycogen and starch in animals and plants. These biopolymers have a number of specific properties, such as biodegradability and compatibility with living body tissue, which opens up great opportunities for their use in practice. The final product of the biodegradation of PHB in the environment is water and carbon dioxide, and in a living organism 3-butobutyric acid.

\section{Acknowledgements}

The authors are sincerely grateful to Olga Kosmachevskaya from the A.N. Bach Institute of Biochemistry, for their advice. This review article was prepared at the initiative of the authors.

\section{REFERENCES}

1. Kalia V.C., Raizada N. and Sonakya V. Bioplastics. Journal of Scientific and Industrial Research., 2000, vol. 59, pp.433-445.

2. Lazarevic D., Aoustin E., Buclet N., Brandt N Plastic waste management in the context of a European recycling society: comparing results and uncertainties in a life cycle perspective. Resour Conserv Recycling, 2010, vol. 55, pp. 246-259.

3. Khosravi-Darani K., Mokhtari Z.B., Amai T., Tanaka K. Appl. Microbiol. Biotechnol. 2013, vol. 97, no. 4, pp. 1407-1424.

4. Halami P.M. Production of polyhydroxyalkanoate from starch by the native isolates Bacillus cereus CFR06. World J. Microbiol. Biotechnol, 2008, vol. 24, no. 6, pp. 805812.

5. European Bioplastics, Nova-Institute Bioplastics market data 2018. Global production capacities of bioplastics 2018-2023. Available at: https ://www.europ ean-bioplastic s.org/wp-conte nt/uploa ds/2016/02/Report_Bioplastic s-Marke t-Data_2018.pdf (accessed 19 May 2020).

6. Christopher J. Brigham and Anthony J. Sinskey Applications of Polyhydroxyalkanoates in the Medical Industry. International Journal of Biotechnology for Wellness Industries, 2012, no.1, pp. 53-60.

7. Sudes K. Synthesis, Structure and properties of polyhydroxyalkanoates: biological polyesters / Prog. Polym. Sci., 2000, vol.25, pp.1503-1555

8. Marchessault R.H. Poly ( $\mathrm{y}^{\wedge}$-hydroxyalkanoates): Biorefinery polymers in search of applications. Macromol. Chem., Macromol.Symp, 2002, vol. 19, pp. 235-254.

9. Hay I.D., Du J., Burr N., Rehm B.H.A., Bioengineering of bacteria to assemble custom-made polyester affinity resins. Appl Environ Microbiol., 2015, vol.81, pp. 282.

10. Lemoigne M. Produits de déshydratation et de polymérisation de l'acideoxybutyrique. Cr Soc Biol., 1926, vol. 8, pp. 770-82.

11. Korneli C., Biedendieck R., David F., Jahn D., Wittmann C. High yield production of extracellular recombinant levansucrase by Bacillus megaterium. Appl Microbiol Biotechnol., 2013, vol.97, pp. 3343-3353.

12. APA Style (2009). Available at: http://www.fengchengroup.net/enzymes-and-bioproducts/probiotics/bacillus megaterium-or-b-megaterium.html (accessed 2019)

13. Tian-Ren Lee, Jer-Sheng Lin, Shih-Shin Wang, and Gwo-Chyuan Shaw, PHAQ, a New Class of PolyHydroxybutyrate (PHB) Responsive Repressor, Regulates PHAQ and PHAP (PHAsin) Expression in Bacillus megaterium through Interaction with PHB Journal of Bacteriology, May 2004, pp. 3015-3021. 
14. Peters V., Rehm B.H. In vivo enzyme immobilization using engineering polyhydroxyalkanoate synthase. Appl Environ Microbiol., March 2006, vol. 72, no. 3, pp. 1777-1783.

15. Braunegg G., Lefebvre G., Genser K.F., Polyhydroxyalkanoates, biopolyesters from renewable resources: Physiological and engineering aspects. J Biotechnol, 1998, vol. 65, pp. 127-161.

16. Braunegg G., Bona R., Koller M., Sustainable Polymer Production. Polymer-plastics technology and engineering, 2004, vol. 43, no. 6, pp. 17791974. https://doi.org/101081PPT-2000042826

17. Sathya A. B., Sivasubramanian V., Santhiagu A., Sebastian C., Sivashankar R. Production of Polyhydroxyalkanoates from Renewable Sources Using Bacteria. Journal of Polymers and the Environment, 2018, vol. 26, no. 9, pp. 39954012. doi:10.1007/s10924-018-1259-7

18. Tan G.Y., Chen C.L., Li L., Ge L., Wang L., Razaad I.M., Li Y., Zhao L., Mo Y., Wang J.Y., Start a research on biopolymer polyhydroxyalkanoate (PHA): a review. Polymers, 2014, vol. 6, no. 3, pp. 706-754.

19. Solaiman D.K.Y., Foglia T.A., Ashby R.A., Marmer W.N., Conversion of agricultural feedstock and coproducts into poly (hydroxyalkanoates). Appl Microbiol Biotechnol, 2006, vol. 71, pp. 783-789.

20. Povolo S., Toffano P., Basaglia M., Casella S. Polyhydroxyalkanoates production by engineered Cupriavidus necator from waste material containing lactose. Bioresource Technol, 2010, vol. 101, pp. 7902-7907.

21. Koller M., Salerno A., Dias M., Reiterer A., Braunegg G. Modern Biotechnological polymer synthesis. Biotechnological Polymer Synthesis, Food Technol Biotechnol, 2010, vol. 48, pp. 255-269.

22. Koller M., Atlic A., Dias M., Reiterer A., Braunegg G. Microbial PHA Production from Waste Raw Materials. Microbiology Monographs, 2010, vol.14, pp. 85-119.

23. Chanprateep S. Current trends in biodegradable polyhydroxyalkanoates. J Biosci Bioeng, 2010, vol. 110, pp.621-632.

24. Chen GQ. Plastics Completely Synthesized by Bacteria: Polyhydroxyalkanoates. In: Chen GQ. (eds) Plastics from Bacteria. Microbiology Monographs, 2010, vol. 14, pp. 17-37. https://doi.org/10.1007/978-3-642-03287-5_2

25. Débora Jung Luvizetto Faccin, Rosane Rech, Argimiro Resende Secchi, Nilo Sérgio Medeiros Cardozo, Marco Antônio ZáchiaAyub, Influence of oxygen transfer rate on the accumulation of poly(3-hydroxybutyrate) by Bacillus megaterium, Process Biochemistry, 2013, Vol. 48, no. 3, pp. 420-425.

26. Kosmachevskaya O. V., Osipov E. V., Tran Van Chi, PHAmThi Tuyet Mai, and Topunov A. F. Effect of Cultivation Conditions on Poly(3-hydroxybutyrate) Synthesis by Nodule Bacteria Rhizobium phaseoli. Applied Biochemistry and Microbiology, 2020, vol. 56, no. 1, pp. 64-71.

27. Grage K., McDermott P., Rehm B.H.A. Engineering Bacillus megaterium for production of functional intracellular materials. Microb Cell Fact, 2017, vol. 16, pp. 211. doi:10.1186/s12934-017-0823-5.

28. Elsayed N. S., Aboshanab K. M., Yassien M. A., \& Hassouna N. H. New insight into poly (3-hydroxybutyrate) production by Azomonas macrocytogenes isolate KC685000: large scale production, kinetic modeling, recovery and characterization. Molecular Biology Reports, 2019, doi:10.1007/s11033-019-04798-4

29. Mohamed M. Khattab, Yaser Dahman, Production and recovery of poly-3hydroxybutyrate bioplastics using agro-industrial residues of hemp hurd biomass, Bioprocess and Biosystems Engineering, 2019, https://doi.org/10.1007/s00449-01902109-6 
30. Songsri Kulpreecha, Atipol Boonruangthavorn, Boonyarit Meksiriporn, and Nuttha Thongchul, Inexpensive fed-batch cultivation for high poly (3 hydroxybutyrate) production by a new isolate of Bacillus megaterium, Journal of Bioscience and Bioengineering, 2009, vol. 107, no. 3, pp. 240-245,

31. Giorgia Pagliano, Valeria Ventorino, Antonio Panico and Olimpia Pepe, Integrated systems for biopolymers and bioenergy production from organic waste and by-products: a review of microbial processes, Paglianoet al. Biotechnol Biofuels, 2017, no.10, pp. 113. https://doi.org/10.1186/s13068-017-0802-4.

32. Díaz-Barrera A., Urtuvia V., Padilla-Córdova C. et al. Poly(3-hydroxybutyrate) accumulation by Azotobacter vinelandii under different oxygen transfer strategies. $J$ Ind Microbiol Biotechnol, 2019, vol. 46, pp. 13-19. https://doi.org/10.1007/s10295018-2090-9.

33. Kulpreecha S., Boonruangthavorn A., Meksiriporn B., Thongchul N. Inexpensive fedbatch cultivation for high poly(3-hydroxybutyrate) production by a new isolate of Bacillus megaterium. J Biosci Bioeng. 2009, vol. 107, pp. 240-245. doi: 10.1016/j.jbiosc.2008.10.006.

34. Ramdane Haddouche \& Yves Poirier \& Syndie Delessert \& Julia Sabirova \& Yves Pagot\& Cécile Neuvéglise\& Jean-Marc Nicaud, Engineering polyhydroxyalkanoate content and monomer composition in the oleaginous yeast Yarrowia lipolytica by modifying the B-oxidation multifunctional protein, Appl Microbiol Biotechnol, 2011, vol. 91, pp. 1327-1340. https://doi.org/10.1007/s00253-011-3331-2.

35. Tripathi A.D., Yadav A., Jha A. Utilizing of Sugar Refinery Waste (Cane Molasses) for Production of Bio-Plastic Under Submerged Fermentation Process. J Polym Environ, 2012, vol.20, pp. 446-453. https://doi.org/10.1007/s10924-011-0394-1

36. Myshkina V. L., Ivanov E. A., Nikolaev D. A., Makhina T. K., Bonartsev A. P., Filatova E. V., Ruzhitsky A. O., Bonartseva G. A., Biosynthesis of a copolymer of poly-3 hydroxybutyrate 3-hydroxyvalerate with a strain of Azotobacter chroococcum7B, Applied biochemistry and microbiology, 2010, vol. 46, no. 3, pp. 315-323.

37. Nemoykina A.L. The accumulation of Alginate and Poly-3-Hydroxybutyrate by the Azotobacter Vinelandii Culture During Cultivation with Different Mixing Frequencies // Innovations in science: collection of works. Art. by mater. XXXV Int. scientificpractical conf. no. 7 (32). - Novosibirsk: SibAK, 2014, pp. 27-31.

38. Ghate B., Pandit P., Kulkarni C., Deepti D.M., Patel T.S., PHB production using novel agro-industrial sources from different Bacillus species. Int J PharmBiosci 2011, no. 2(3), pp. 242-249.

39. Medjeber N., Abbouni B., Menasria T, Beddal A., Cherif N. Screening and production of polyhydroxyalcanoates by Bacillus megaterium by using cane and beet molasses as carbon sources. Der Pharm Lett, 2015, no. 7(6), pp. 102-109.

40. Bhuwal A.K., Singh G., Aggarwal N.K., Goyal V., Yadav A. Poly- $\beta$-hydroxybutyrate production and management of cardboard industry effluent by new Bacillus sp. NA10. Bioresour Bioprocess, 2014, no. 1(9), pp. 1-11.

41. Gumel A.M., Annuar M.S.M., Heidelberg T. Growth kinetics, effect of carbon substrate in biosynthesis of mcl-PHA by Pseudomonas putida Bet001. Braz J Microbiol, 2014, no. 45, pp. 427-438.

42. Redzwan G., Gan S.N., Tan I.K.P. World J. Microbiol. Biotechnol. 1997, vol.13, pp.707-709.

43. Charen T., Vaishal I.P., Kaushalya M., Amutha K., Ponnusami V., Gowdhaman D. Int. J. Chem Tech. Res. 2014, no. 6(5), pp. 3197-3202.

44. Khanna S., Srivastava A.K. Recent advances in microbial polyhydroxyalkanoates. Process Biochem, 2005, no. 40(2), pp. 607-619. https://doi.org/10.1016/j.procb io.2004.01.053 
45. Muhammadi, Shabina, Muhammad Afzal \& Shafqat Hameed Bacterial polyhydroxyalkanoates-eco-friendly next generation plastic: Production, biocompatibility, biodegradation, physical properties and applications, Green Chemistry Letters and Reviews, 2015, vol. 8, no. 3-4, pp. 56-77, https://doi.org/10.1080/17518253.2015.1109715

46. Ezhov V. A., Doronina N. V., Shmareva M. N., Trotsenko Yu. A., Synthesis of high molecular weight polyhydroxybutyrate from methanol Methyloligella halotolerans $C 2$, Applied Biochemistry and Microbiology, 2017, vol. 53, no. 1, pp. 55-60.

47. Nehra K., Chhabra N., Sidhu P.K., Lathwal P., Rana J.S. Asian J Microbiol Biotech Environ Sci, 2015, no. 17(4), pp. 281.

48. Law J.H., Slepecky R.A. Assay of poly-13-hydroxybutyric acid. J Bacteriol, 1961, vol.82(1), pp.33-36.

49. Priyanka Lathwal, Kiran Nehra, Manpreet Singh J. S. Rana, Characterization of Novel and Efficient Poly-3-hydroxybutyrate (PHB) Producing Bacteria Isolated from Rhizospheric Soils, Journal of Polymers and the Environment, 2018, https://doi.org/10.1007/s10924-018-1224-5

\title{
ҚАЙТА ЖАНАРТЫЛАТЫН КӨЗДЕРДЕН АЛЫНАТЫН ПОЛИГИДРОКСИБУТИРАТТАРДЫ МИКРОБИОЛОГИЯЛЫК ӨНДІРУ
}

\author{
Рысбек А.Б. ${ }^{1,2}$, Құрманбаев А.А. ${ }^{1}$ \\ ${ }^{1}$ Ұлттық биотехнология ортальгы \\ Қорвалжын тасжолы 13/5, Нұр-Сұлтан, к., 010000, Қазақсстан \\ ${ }^{2}$ Л.Н. Гумилев Еуразия ұлттық университеті, \\ Сәтпаев 2 көш., Нұр-Сұлтан к., 010008, Қазақсттан \\ aidana.rysbek9@yandex.ru
}

\section{ТYЙІН}

Пластмассалар күнделікті өмірімізде маңызды рөл атқарады және әртүрлі мақсаттарда қолданылады. Экологиялық таза өнімдердің өндірісі бүгінде биопластиканы қосқанда белсенді дамып келеді. Қазіргі уақытта ғалымдар әртүрлі микроорганизмдер қосалқы зат ретінде синтезделетін полигидроксибутираттар сияқты полигидроксилаканоаттар немесе оның қосалқы типтері сияқты сонымен қатар кәдімгі синтетикалық пластмассалардың орнына қолдануға болатын биологиялық ыдырайтын полимерлерге үлкен назар аударады. Алайда, мұндай биологиялық ыдырайтын полимердің ірі көлемдегі өндіріс құны оның кең таралуына бәсекеге қабілетті емес. Полигидроксибутираттар микроб өндірісін зерттеу экономикалық тұрғыдан тиімді субстраттарды анықтауға, сонымен қатар өндіріс үшін дененің тиісті штамдарын анықтауға бағытталуы керек. Бұл биополимерлер бірқатар биологиялық ыдырау және тірі дене ұлпаларымен үйлесімділік сияқты бірқатар ерекше қасиеттерге ие, бұл оларды практикада қолдануға үлкен мүмкіндіктер береді. Қоршаған ортадағы полигидроксибутираттар биодеградациясының соңғы өнімі су мен көміртегі диоксиді, ал тірі организмде 3-изомеразды қышқылы. Бұл шолудың негізгі бағыты бактериялардың әртүрлі түрлерін қолдана отырып, әртүрлі экономикалық субстраттардан биопластик өндіруге бағытталған. 
Негізгі

сөздер:

биополимер,

полигидроксибутират, полигидроксиалканоат, қалпына келтірілетін қайнар көз, микроб өндірісі, арзан көміртек көздері; мерзімді өсіру.

\title{
МИКРОБИОЛОГИЧЕСКОЕ ПРОИЗВОДСТВО ПОЛИГИДРОКСБУТИРАТОВ ИЗ ВОЗОБНОВЛЯЕМЫХ ИСТОЧНИКОВ
}

\author{
Рысбек А.Б. ${ }^{1,2,}$ Курманбаев А.А. ${ }^{1}$ \\ ${ }^{1}$ Национальный ичентр биотехнологии» КН МОН РК, \\ Коргалжинское шоссе, 13/5, г. Нур-Султан, 010000, Казахстан. \\ ${ }^{2}$ Евразийский Национальный Университет им. Л.Н. Гумилева, \\ ул. Сатпаева, 2, г. Нур-Султан, 010000, Казахстан. \\ aidana.rysbek9@yandex.ru
}

\begin{abstract}
АБСТРАКТ
Пластмассы играют важную роль в нашей повседневной жизни и используются для различных целей. Индустрия экологичных продуктов в наше время активно развивается, в том числе биопластиков. Большое внимание ученых привлекают биоразлагаемые полимеры типа полигидроксиалаканоаты или полигидроксибутираты, которые синтезируются различными микроорганизмами как запасное вещество и, к тому же, являются наиболее приемлемой заменой обычных синтетических пластиков. Однако стоимость крупномасштабного производства такого биоразлагаемого полимера не является конкурентноспособной его широкому распространению. Исследования микробной продукции полигидроксибутиратов должны быть направлены на выявление экономически эффективных субстратов, а также определение подходящего штамма организма для производства. Эти биополимеры обладают рядом специфических свойств. Например, способность к биодеструкции и совместимость с живой тканью организма, что открывает большие возможности для их использования в практике. Конечным продуктом биодеградации полигидроксибутиратов в окружающей среде является вода и двуокись углерода, а в живом организме - 3-изомасляная кислота. Основное внимание в этом обзоре уделено производству биопластиков из различных экономичных субстратов с использованием различных видов бактерий.

Ключевые слова: биополимер, полигидроксибутират, полигидроксиалаканоат, возобновляемый источник, микробное производство, дешевые источники углерода, периодическая культура.
\end{abstract}

